\title{
19. INTRODUCTION TO ORGANIC GEOCHEMISTRY STUDIES, DSDP LEG 44
}

\author{
Keith A. Kvenvolden, U.S. Geological Survey, Menlo Park, California
}

Four sites cored on DSDP Leg 44 provided geochemists an opportunity to evaluate the organic matter in sediments of the western part of the North Atlantic Ocean. Of special interest were studies of potential petroleum sources offshore of the eastern United States. Therefore, the JOIDES Advisory Panel on Organic Geochemistry recommended that preliminary data be made available to those who make decisions concerning the exploration and exploitation of this area. Eight preliminary papers were included in an informal open file report compiled by the Organic Geochemistry Panel and printed by the Deep Sea Drilling Project. Final versions of these eight papers plus three others follow.

Thirty-seven core segments and five canned samples were collected for distribution and study by the Organic Geochemical Panel. Additional samples were obtained on shipboard for three special investigations. Core sections, ranging in age from Late Jurassic to Pleistocene, were frozen immediately on board ship and kept frozen until sampling was completed on shore. Sampling took place at the DSDP West Coast Repository in La Jolla, California. The frozen cores were opened, sawed longitudinally, and portions of the cores were sealed in mylar bags for shipment in dry ice to various laboratories. At least one-eighth and usually one-fourth of the sampled core segments were left frozen at the DSDP facility. Portions of these samples (Table 1) are available for further investigations.

A wide variety of analytical techniques has been applied to these sediment samples to evaluate their potential as petroleum sources. Interpretations resulting from these data do not always agree; the following statements briefly summarize the major observations. (References to papers in this volume are indicated by the name of the first author in parentheses.) The organic carbon content of the sediments ranges from about 0.1 to 3.4 per cent. Sources of organic matter are both marine and terrestrial; for the Cretaceous carbonaceous shales most investigators (Deroo; Dow; Cardoso; Kendrick; Stuermer) suggest a dominantly terrestrial source on the basis of considerations of lipids, humic acids, and kerogen. On the other hand, two groups of investigators (Erdman; McIver) suggest or imply, on the basis of lipid and carbon isotopic compositions, that a major part of the Cretaceous organic matter is from marine sources. The organic matter is generally considered to be thermally immature (Deroo; Dow; Cardoso; Claypool; Kendrick; McIver) having undergone little diagenetic alteration since deposition. An exception is the interpretation of one group (Erdman) that liquid petroleum genesis is well advanced in certain older sediment samples. The organic matter in some samples is considered a
TABLE 1

Inventory of Frozen Core Segments, Leg 44

\begin{tabular}{|c|c|c|c|}
\hline Hole & Core & Section & Interval $(\mathrm{cm})$ \\
\hline $388 \mathrm{~A}$ & 5 & 0 & $0-40$ \\
\hline $388 \mathrm{~A}$ & 7 & 3 & $0-40$ \\
\hline $388 \mathrm{~A}$ & 11 & 0 & $0-50$ \\
\hline 390 & 3 & 3 & $0-20$ \\
\hline $390 \mathrm{~A}$ & 6 & 0 & $0-40$ \\
\hline $390 \mathrm{~A}$ & 10 & 0 & $0-45$ \\
\hline $390 \mathrm{~A}$ & 21 & 0 & $0-45$ \\
\hline 391 & 1 & 2 & $0-20$ \\
\hline $391 \mathrm{~A}$ & 3 & 4 & $0-28$ \\
\hline 391A & 4 & 3 & $0-40$ \\
\hline $391 \mathrm{~A}$ & 5 & 0 & $0-40$ \\
\hline $391 \mathrm{~A}$ & 6 & 3 & $0-20$ \\
\hline $391 \mathrm{~A}$ & 9 & 0 & $0-50$ \\
\hline $391 \mathrm{~A}$ & 10 & 0 & $0-40$ \\
\hline $391 \mathrm{~A}$ & 11 & 0 & $0-33$ \\
\hline $391 \mathrm{~A}$ & 12 & 0 & $0-35$ \\
\hline $391 \mathrm{~A}$ & 13 & 0 & $0-45$ \\
\hline $391 \mathrm{~A}$ & 20 & 0 & $0-40$ \\
\hline $391 \mathrm{~A}$ & 21 & 4 & 2-125 \\
\hline 391B & 2 & 1 & $13-40$ \\
\hline $391 \mathrm{C}$ & 2 & 0 & $0-43$ \\
\hline $391 \mathrm{C}$ & 6 & 3 & $0-42$ \\
\hline $391 \mathrm{C}$ & 6 & 3 & 44-145 \\
\hline $391 \mathrm{C}$ & 7 & 2 & $110-130$ \\
\hline $391 \mathrm{C}$ & 8 & 3 & $115-143$ \\
\hline $391 \mathrm{C}$ & 9 & 3 & $0-48$ \\
\hline $391 \mathrm{C}$ & 9 & 3 & $50-145$ \\
\hline $391 \mathrm{C}$ & 10 & 3 & $110-142$ \\
\hline $391 \mathrm{C}$ & 11 & 2 & $110-143$ \\
\hline $391 \mathrm{C}$ & 12 & 4 & $0-46$ \\
\hline $391 \mathrm{C}$ & 12 & 4 & $50-125$ \\
\hline $391 \mathrm{C}$ & 16 & 1 & $110-150$ \\
\hline $391 \mathrm{C}$ & 21 & 3 & $110-138$ \\
\hline $391 \mathrm{C}$ & 26 & 3 & $110-150$ \\
\hline $391 \mathrm{C}$ & 30 & 2 & $110-150$ \\
\hline $391 \mathrm{C}$ & 35 & 4 & $0-30$ \\
\hline $391 \mathrm{C}$ & 40 & 2 & $0-38$ \\
\hline $391 \mathrm{C}$ & 48 & 2 & $125-150$ \\
\hline $391 \mathrm{C}$ & 52 & 2 & $10-40$ \\
\hline
\end{tabular}

potential source for hydrocarbon gas (Deroo; Dow; Hunt) and possibly for oil (Erdman; McIver).

Some other observations are: (1) Gas analyses show very low concentrations of light hydrocarbons (Hunt; McIver), a result not unexpected in organically immature sediments. (2) The presence of free-base chlorins (Baker) supports the postulation of a mild thermal history for these sediments. (3) The assortment of pigments (Baker) and the presence of recycled vitrinite (Dow; Cardoso; Kendrick) suggest sediment reworking. (4) Carbohydrates which can be characterized are generally low in concentration in spite of moderate concentrations of total carbohydrates (Swain). (5) Lipid extracts have not been contaminated by products of the drilling operation (McIver). 